\title{
PERFORMANCE EVALUATION OF CZECH INNOVATIVE COMPANIES: DATA ENVELOPMENT ANALYSIS APPROACH
}

\author{
Miroslav ŽIŽKA ${ }^{\text {a,** Vladimíra HOVORKOVÁ VALENTOVÁ }}{ }^{\mathbf{b}}$, Lukáš TURČOK ${ }^{\text {a }}$ \\ ${ }^{a}$ Department of Business Administration and Management, Faculty of Economics, Technical University \\ of Liberec, Studentska 2, 46117 Liberec, Czech Republic \\ ${ }^{b}$ Department of Economic Statistics, Faculty of Economics, Technical University of Liberec, Studentska 2, 461 \\ 17 Liberec, Czech Republic
}

Received 4 March 2016; accepted 10 June 2016

\begin{abstract}
The article deals with the verification of a performance evaluation model of innovative companies in the Czech Republic and the evaluation of the impact of a branch on their performance in terms of effectiveness and efficiency. From a methodological point of view, the article is based on the use of Data envelopment analysis (DEA) to evaluate the performance of the selected companies. To evaluate their performance, a two-stage DEA method, BCC model orientated at inputs is used. In the first stage, the effectiveness of resources spent on protecting industrial property rights is evaluated. In the second stage, it is assessed how the companies managed to evaluate registered property rights in terms of added value. The research results show that among branches, there are significant differences in both the overall level of performance, and in its pillars - effectiveness and efficiency. In the conclusion, other potential factors that could affect the company's performance in terms of effectiveness and efficiency are discussed.
\end{abstract}

KEYWORDS: Data envelopment analysis; BCC model; Innovative companies; Effectiveness; Efficiency

\section{INTRODUCTION}

Company performance is one of the current, but not uniformly comprehended topics in the literature, both in terms of the definition of "performance" and in terms of its measurement. As reported by Lebas (1995): "The term performance is even more frustrating to define than measures are." Lebas emphasizes that performance, particularly in management, is not so much about the past performance of the company, but rather about the future, about the ability of companies that are evaluated. However, the performance evaluation is the basis for understanding the sources of company competitiveness and the implementation of business strategy. Therefore, it is important that companies understand the performance and manage to monitor it, not only from a financial perspective (Štamfestová 2014). Increasingly, therefore, when measuring the performance of companies, non-financial measures and multidimensional concepts exemplified by Balanced Scorecard are applied (Knápková et al. 2014). Company performance is

* Corresponding author. E-mail: miroslav.zizka@tul.cz also affected by various factors at the macro- and micro-level (Tausl Prochazkova et al. 2015).

Company performance has two basic dimensions. The first dimension is the choice of activities to achieve business objectives; this dimension is called effectiveness. The second dimension relates to the implementation of the activity, i.e. the ability of the company to achieve outcomes with minimal inputs (costs). This dimension is called efficiency (Wagner 2009; Karlíček et al. 2014). Performance can then be regarded as an appropriate combination of effectiveness and efficiency (Kumar, Gulati 2010). A powerful company should, therefore, act efficiently and effectively.

If the company wants to influence and manage performance, it must also establish a system enabling it to quantify and compare the performance (in time, within the branch, with competitors). For performance measurement, it is, therefore, necessary to define the reference value and to measure the difference between this reference value and the evaluated company or the production system (Triantis, Otis 2004). Approaches to performance 
measurement can be divided into four main categories using simple ratios, a set of pyramid indicators, composite indicators, multivariate and multi-criteria methods.

The multi-criteria programming method called Data Envelopment Analysis (hereafter DEA) was used in this article to evaluate the performance of companies. This method enables the evaluation of companies with the help of the large number of both financial and non-financial inputs and outputs and also can identify the best companies, or in other words benchmarks.

The article builds on previous research in which the model was designed to evaluate the performance of innovative companies. The model was tested on the example of two branches (Budaj et al. 2015; Žižka, Turčok 2015). The aim of the follow-up research, whose results are discussed in this article, was to find out whether the model applies generally to other branches. Furthermore, the article raises the question of whether there are significant differences in the performance of companies across branches in terms of effectiveness and efficiency. The article also looks at the variables that can affect the performance of companies in different branches.

\section{CHARACTERISTICS OF DATA ENVELOPMENT ANALYSIS}

DEA was used in the article as the basic tool for evaluating the performance of companies. For this reason, the main characteristic of this method is briefly presented at the beginning of the article. In the following chapter, there is a review of literature, focused on the use of DEA in solving specific decision-making situations in business practice. DEA is a non-parametric method of multi-criteria linear programming used to evaluate the effectiveness and efficiency of homogenous decision-making units (hereafter DMUs). This set of homogeneous units is enveloped with efficient frontier whose shape depends on the nature of returns to scale. The authors of this method are Charnes, Cooper and Rhodes who first published it in 1978. The first model, called CCR according to the authors' last names, was based on the assumption of constant returns to scale (Charnes et al. 1994). Their work, however, continued the pioneering work of Farell from 1957 dealing with technical efficiency measurements using linear programming. In 1984, Banker, Charnes and Cooper generalized the model for technologies where there are increasing, constant and diminishing returns to scale, in general, variable returns to scale (Ray 2004). This model is referred to as BCC according to the authors' last names. Basic CCR and BCC models may be input or output oriented, depending on whether the units may affect primarily their inputs or outputs. DEA models work with relative technical efficiency which, in the case of models oriented at inputs, is calculated by equation (1), see e.g. (Fiala et al. 2010; Luptáčik 2010). In the case of models oriented to outputs, numerator and denominator are reversed. An important feature of the DEA models is that the individual inputs and outputs are weighted (in relation (1) it is weight $u_{i}$ for the outputs, or $v_{j}$ for inputs), for each unit separately so as to maximize the degree of efficiency of these units. The technical efficiency coefficient of units at the efficient frontier equals one. This means that there is no unit which achieves the same outputs with lower inputs, or higher outputs with the same inputs. This condition is expressed by Pareto-Koopman's concept of efficiency: "Full efficiency is attained by any DMU if and only if none of its inputs or outputs can be improved without worsening some of its other inputs or outputs." (Cooper et al. 2011).

$$
\begin{aligned}
& \frac{\text { weighted sum of outputs }}{\text { weighted sum of inputs }}=\frac{\text { virtual output }}{\text { virtual input }}= \\
& \frac{\sum_{i} u_{i} y_{i k}}{\sum_{j} v_{j} x_{j k}}
\end{aligned}
$$

The outcome of the primary model solution is input and output weights and coefficients of technical efficiency of individual DMUs. By solving the dual model, weights of peer units for inefficient production units can be searched. Thus, DEA provides the decision-maker with the information on how the behaviour of the evaluated DMU should be improved to become efficient (Fiala et al. 2010). Besides the basic models of CCR and BCC, a number of other modifications have been developed in later years. These are, for instance, models assuming that some of the inputs or outputs are not under the control of management (i.e. nondiscretionary inputs/outputs), models with categorical inputs and outputs acquiring a certain level, models with restrictions of possible range of weights, models with repeated evaluation of performance units in the time series, additive models concurrently maximizing output and minimizing inputs, multicomponent DEA models and others (Charnes et al. 1994; Cooper et al. 2011). 


\section{LITERATURE REVIEW}

DEA investigates the efficiency or performance of homogenous production units. This property is ideal for applications particularly in the field of mass services and the evaluation of units within the branch network. Therefore, this method is quite frequently used in banking and insurance sectors (for example Grmanová 2013; Hajiagha et al. 2013; Ho, Zhu 2004; Kočišová 2014; Kumar, Gulati 2010), real estate and construction sectors (Jin et al. 2015; Horta et al. 2016; Cheng, Chen 2014; Yang et al. 2016; Hu, Liu 2016) when evaluating universities (for example Nazarko, Šaparauskas 2014; Rosenmayer 2014; Žižka 2015), hospitals (for example Dlouhý 2015) and transport enterprises (for example Klieštik 2009; Lin et al. 2012).

The influence of defining branches on the results of DEA is evident from the research on the performance of 480 major Turkish industrial companies. In the case of performance analysis across branches, only 9 efficient firms were identified. When dividing the companies into 12 industries, 65 efficient companies were found (Düzakin, Düzakin 2007). The above mentioned study also dealt with the issue of the definition of inputs and outputs that should be independent. On the input side, a strong correlation was found between net assets and company equity. Therefore, only company net assets and number of employees were left in the analysis. On the output side, sales and gross sales quantities were eliminated as unsuitable since they do not take into account the profit margin. Gross value added, profit before tax and export revenues were defined as suitable outcomes (Düzakin, Düzakin 2007).

The study of Czech innovative companies in the textile industry focused on the detection of a relationship between inputs and outputs when creating DEA models. In this industry, a strong correlation was found between the number of employees and long-term capital, and a weaker correlation between the number of employees and the period of existence of the company. On the contrary, no significant correlation was found between the time of the company's existence and long-term capital. Long-term capital and the period of existence of the company, which was seen as a form of accumulated intellectual capital, were, therefore, used as inputs to the DEA model in the study of textile enterprises (Žižka, Turčok 2015).

A multistage DEA method can be applied in complex production processes and supply chains. Extensive production processes and chains are characterized by a number of related sub-processes and echelons where outputs of one sub-process, for example in the form of semi-finished products, are used as inputs into a consequent sub-process. Multistage DEA method enables the distribution of overall efficiency to individual components and thus it is possible to easily identify sources of inefficiency (Liu, Wang 2009; Hu, Liu 2016).

In study on the high-tech industry in China, the production process was divided into the stages of technological development and commercialization. The amounts of FTE researchers, internal R\&D costs and original value of facilities were used as inputs to the first stage of development. The outputs of this stage were evaluated using a number of projects, project applications and owning patents. These outputs were then used as inputs to the second stage of the evaluation. The outputs of the stage of commercialization included the sales from new products and revenues from exports of new products (Chen et al. 2013). In a study of 400 companies in South Korea, the efficiency of innovations and their commercialization was measured using DEA method. At the input, the productivity of innovations was evaluated using the investments in internal and external R\&D and the number of R\&D employees and at the output, using the number of product and process patent applications. At the output, commercialization efficiency was measured by volume of sales and by operating income (Chun et al. 2015). Similar research in the Czech Republic was aimed at evaluating the performance of innovative companies in the automotive industry. The overall performance here was evaluated in two stages in terms of effectiveness of the protection of industrial property rights and the effectiveness of their commercialization (Budaj et al. 2015).

A further study of innovative companies in the Czech textile industry worked with regard to correlation of inputs and outputs only with two inputs (long-term capital, the period of company existence) and two outputs (patents and utility models, industrial designs and trademarks) in the first stage. The output of the second stage was added value (Žižka, Turčok 2015). The two-stage system of measuring the relationship between operational performance and corporate governance was used in research into 270 leading Japanese companies. In the first stage, DEA was carried out in order to evaluate the operational performance. Normalized coefficients of technical efficiency were used in the second stage as a dependent variable in a Tobit regression analysis. The independent variables were 
variables characterizing corporate governance. The research found a nonlinear dependence between operational performance and foreign shareholding of Japanese companies. The results imply that Japanese companies should, to some extent, open up to foreign capital (Sueyoshi et al. 2010).

DEA can serve as a holistic evaluation tool of the greenness of production, both within a particular branch and between branches (Salem, Deif 2014). The two-stage approach was used to evaluate the eco-efficiency of French companies. Eco-efficiency was divided into two parts: resource efficiency and eco-efficiency (Lahouel 2015). A similar problem of measuring environmental performance using DEA was solved in Chinese industrial companies. Capital, personnel and facilities in the field of environmental management were used as inputs and different types of waste and the value of production from recycled materials were used as outputs. The results showed the persistent low efficiency of environmental management of Chinese companies. At the same time, however, they revealed significant differences between branches. Higher efficiency of environmental management was found in industries that have a high rate of energy consumption and produce large amounts of pollution. This is the result of continual monitoring by the Ministry of Environmental Protection (Xie et al. 2015).

An important factor in corporate performance is intellectual capital. In a study focused on the performance of luxury yachts producers in Italy, three inputs were used and two outputs correlated with intellectual capital. These were the proportion of specialized professions in the total number of employees, investment in relation capital and expenditure in $R \& D$ on the input side. On the output side, these were the number of product and process innovations and the yearly turnover in euros. Depending on the level of competitiveness and growth, companies were divided into four groups: high competitiveness/rapid growth, high competitiveness/slow growth, low competitiveness/ rapid growth and low competitiveness/slow growth (Costa 2012).

The combination of DEA and the discriminative analysis was used to determine whether the expenditure on research and development affect the financial performance of Japanese companies. Companies were divided into two groups - the companies in default and healthy companies, while each group of companies was characterized by multiple indicators (for example by the intensity of $R \& D)$. It was found that $R \& D$ expenditures had a positive impact on the performance of companies in the engineering industry, however negative in the electrotechnical industry. The result is influenced by different life cycles of facilities and the competitive environment in the surveyed branches of industry (Sueyoshi, Goto 2009).

Aristovnik and Obadić (2015) used DEA to evaluate the impact of selected indicators of public administration in the EU on the growth and performance of SMEs. The results of the research showed that in terms of SMEs activity and the influence of public administration on the business environment, the surveyed countries can be divided into four groups. The most efficient units include the Baltic countries, Luxembourg and Sweden. These countries are characterized by low bureaucracy and high quality business environment which are reflected in the parameters of the SMEs growth.

\section{DATA AND METHODOLOGY}

The research was aimed at the two-stage evaluation of the performance of innovative companies in the Czech Republic. The article asks the following research questions:

- Can the proposed model to evaluate the performance of companies (in terms of efficiency and effectiveness) be applied in all branches?

- Are there significant differences in company performance within branches?

- What factors affect the performance of companies in various branches?

To answer the above questions, there were formulated fundamental hypotheses:

- Scores of effectiveness and scores of efficiency are uncorrelated.

- Scores of effectiveness and scores of performance are uncorrelated.

- Scores of efficiency and scores of performance are uncorrelated; for more details see step 6 .

- Score of effectiveness does not depend on branch.

- Score of efficiency does not depend on branch, for more details see step 7 .

The research process can be divided into the following steps:

Step 1: Creating a list of evaluated companies a population of innovative companies was found in the Technological Profile CR database (AIP CR 2015). The database is continuously updated. The database includes various innovative institutions such as universities, research organizations, science parks and also innovative businesses. For the purposes of this research, only innovative companies were chosen. 
The registration of companies in the database is voluntary and any company that is considered to be innovative can register. The database contains basic information (name, address, contact information, number of employees, industry, technology, type of organization), according to which companies can be selected. All the companies involved in branches 10-33 according to the NACE classification were filtered out of the database. All the branches, in which at least 30 business entities were registered, were included in the survey. This condition was fulfilled in 15 branches in which almost 2.5 thousand companies were registered (see Table 1).

Step 2: Creating a shortlist of innovative companies - as companies can register into the Technological profile database at their discretion, it is likely that some companies will register only for marketing reasons without actually being innovative. For this reason, a narrower definition of an innovative company was used. The innovative company is such a body which has at least one active protected result of a patent type, utility model, industrial design or trademark registered in the database of the Industrial Property Office. For this purpose, extensive research in the database of the Industrial Property Office was done. The numbers of aforementioned property rights were determined for all companies identified in step 1 . In total, almost 1.5 thousand companies were identified with one or more of the above mentioned forms of registered industrial rights (see Table 1). The collection of corporate data was conducted between November 2014 and May 2015.

Step 3: Inputs and outputs of the model - based on pilot research in two branches (Budaj et al. 2015, Žižka, Turčok 2015), where the performance was measured from two perspectives - two types of models were created. The first model evaluated the effectiveness of resources spent on protecting industrial property rights. The period of existence of the company $D E$ (including legal predecessors) and long-term capital $D K$ were used as inputs. The period of a company's existence can be considered a form of accumulated intellectual capital involving technological trajectory, routines, know-how, skills and experience of owners and employees. It was determined according to the data in the commercial register and the information on the websites of companies. A long-term capital includes equity, long-term payables and long-term bank loans. It represents the total financial resources invested in business by owners and creditors in order to make a profit. Data source was Magnus Web CZ data- base (Bisnode 2015) which includes balance sheets and profit and loss statements which companies are required to disclose according to the Czech Accounting Act.

Table 1. The numbers of analyzed companies by branches

\begin{tabular}{llllll}
\hline NACE & 1 & 2 & 3 & 4 & 5 \\
\hline $10+11$ & 48 & 37 & 34 & 1 & 33 \\
13 & 55 & 36 & 41 & 5 & 36 \\
16 & 40 & 17 & 16 & 1 & 15 \\
18 & 48 & 35 & 29 & 1 & 28 \\
20 & 152 & 118 & 105 & 1 & 104 \\
22 & 163 & 87 & 84 & 2 & 82 \\
23 & 89 & 63 & 62 & 0 & 62 \\
24 & 79 & 47 & 44 & 0 & 44 \\
25 & 484 & 268 & 253 & 1 & 252 \\
26 & 305 & 187 & 158 & 1 & 157 \\
27 & 322 & 185 & 169 & 2 & 167 \\
28 & 494 & 290 & 276 & 2 & 274 \\
29 & 79 & 35 & 28 & 0 & 28 \\
30 & 63 & 42 & 39 & 0 & 39 \\
31 & 36 & 19 & 17 & 1 & 16 \\
\hline Total & 2,457 & 1,466 & 1,355 & 18 & 1,337 \\
\hline
\end{tabular}

Notes: 1 - number of companies that are listed in the database of the Technological Profile of the Czech Republic, 2 - number of companies with at least one registered protection of industrial property rights, 3 - number of companies with available financial statements, 4 - inactive companies, 5 - number of companies analyzed.

The model outputs are patents, utility models, industrial designs and trademarks. Since it was necessary to fulfil the requirement of non-zero outputs in all the analyzed units in all branches, categories of patents and utility models (PUV) and the categories of industrial designs and trademarks (PVOZ) were merged. The first model, thus, worked with two inputs and two outputs. The second model evaluated performance in terms of efficiency, which means how the companies managed to evaluate the registered rights in the form of added value $P H$. The data on added value was also obtained from the Magnus Web CZ database (Bisnode 2015). The inputs to the second model were, therefore, identical with the outputs of the first model. The output of the second model was the added value. The second model worked with two inputs and one output. Unfortunately, although there is a disclosure requirement for companies given by the Accounting Act, a number of companies do not respect it or send the data to the commercial register with a delay. For this reason, the data for 2012, where the maximum amount of information could be found, was used. Companies 
with zero sales and put into liquidation, therefore inactive companies, were also excluded from the database. The resulting number of analyzed companies is given in the last column of Table 1 .

Step 4: Formulation of a mathematical model - based on a previous pilot study, there were found increasing returns to scale in the automotive industry (Budaj et al. 2015) and decreasing returns to scale in the textile industry (Žižka, Turčok 2015). Therefore, the BCC model oriented toward inputs was preferred. The aim of a model solution is to minimize the objective function $z(2)$ under restrictive conditions (3). The $x_{i}$ symbol labels model inputs $(i=1,2, \ldots r), y_{i}$ are model outputs, $v_{j}$ weight inputs $(j=1,2, \ldots m), u_{i}$ are weight outputs. The value of $\mu$ indicates the deviation from constant returns to scale.

$$
\begin{aligned}
& z=\sum_{\mathrm{i}}^{r} u_{i} y_{i q}+\mu \\
& \sum_{i}^{r} u_{i} y_{i k}-\sum_{j}^{m} v_{j} x_{j k}+\mu \leq 0, k=1,2, \ldots, n \\
& \sum_{j}^{m} v_{j} x_{j q}=1 \\
& u_{i} \geq \varepsilon, i=1,2, \ldots, r ; \\
& \varepsilon-\operatorname{very} \text { small non-Archimedean number }(>0) \\
& v_{j} \geq \varepsilon, j=1,2, \ldots, m, \\
& \mu \in R
\end{aligned}
$$

Step 5: Solving mathematical models - for each DMU, an effectiveness score, an efficiency score and a performance score were set. The performance score is the product of scores of effectiveness and efficiency. Furthermore, the average scores of effectiveness, efficiency and performance were calculated for the whole industry, including the sample standard deviation. To solve the models, the Solver Add-in program in Excel and specialized OSDEA-GUI software were used.

Step 6: Correlation Analysis - using Pearson product moment correlation coefficients, the correlation between the scores of effectiveness, efficiency and performance was evaluated. Finally, the companies were divided into four quadrants based on the relationship between effectiveness and efficiency, which is a modified Boston Consulting Group matrix. The companies, whose scores of effectiveness and efficiency were bigger than 0.5 inclusive, were included in the best quadrant of "super star" companies. At the other extreme, there are companies in the quadrant of "problem children" with scores of effectiveness and efficiency less than 0.5. In the "cash cows" quadrant, there are companies with a score of effectiveness of less than 0.5 while the score of efficiency is bigger than 0.5 inclusive. The last quadrant of "question marks" includes companies with a score of effectiveness bigger than 0.5 inclusive, but at the same time with an efficiency score of less than 0.5.

Step 7: Assessment of differences among sectors - using the Kruskal-Wallis test and one-way analysis of variance, it was examined whether there are statistically significant differences between the medians, or means of scores of effectiveness or efficiency of individual industries. Based on the results of Levene's test, which is used to verify the homoscedasticity, two different methods were selected. Levene's test was used since the ShapiroWilk test showed that the distribution of effectiveness and efficiency scores is not normal. When examining the dependence of effectiveness on the type of branch, Levene's test led to the rejection of the null hypothesis on equality of variance of each group. That is the reason why the Kruskal-Wallis test was used rather than the analysis of variance. The test was further completed by the findings of statistically significant differences between the means of each branch. For this purpose the Bonferroni method was used. When examining the dependence of effectiveness on the type of industry sector, the analysis of variance was used because Levene's test confirmed the equality of variance of each group. The analysis of variance was supplemented by the Multiple Range Test which is used to determine statistically significant differences between the means of each branch.

\section{RESEARCH RESULTS}

For each company in the given branch, the score of effectiveness, efficiency and performance was determined. Subsequently, an average score of effectiveness, efficiency and performance for the entire branch was calculated (see Table 2). A cofactor to the average values in Table 3 shows by how many percent on average the companies in the given branch should decrease their inputs (while maintaining a given level of outputs) to become efficient at a given level. It was further examined in how many companies the relevant score was equal to one, that means, was on the efficient frontier. These benchmark numbers are listed in the "frontier" columns in Table 2.

Table 2 shows that there are differences among branches in both the overall level of performance, and also in its individual segments. There are significant differences in the numbers of the best companies if the effectiveness and efficiency is 
evaluated in individual branches or if it is evaluated as a whole unit. When the analysis is made for the sector as a whole, the difference is not so obvious. When the analysis was carried out branch by branch, in an "effectiveness" pillar, 133 best companies were found. However, when the same data was used for all branches together, the number of best companies decreased to 3 . In the event of an "efficiency" pillar, the difference was less significant (379 vs. 250), yet noteworthy. Only 25 companies in the given branch also acted effectively and efficiently, that is, their performance scores were equal to one. In the case of cross-sectoral evaluation, no company with a maximum score of performance was identified. The cause of these differences is the fact that the sector cannot be considered a homogeneous group. Even when the same categories of inputs and outputs in all branches were used in DEA, internally, they are not the same branches. They make different products, they have different profitability and diverse production functions.

Similar heterogeneous results were found when dividing companies into four quadrants based on the relationship between the scores of effectiveness and efficiency (Table 3). The highest proportion of successful companies within the "super stars" group (54\%) was found in NACE Division 29; while in NACE Division 20 not a single company was included. It can be implied that companies in the automotive branch put considerable emphasis on protecting the results of technical creative activity and at the same time they strive to draw economic benefits from this protection. The highest share of problematic companies (62\%) was identified in NACE Division 20. Conversely, no firm in that group was in NACE Division 31. A high proportion of companies in the category of "cash cows" (48\%) was typical for NACE Division 28; NACE Division 29 had the smallest proportion (11\%) in this category. This illustrates the efforts which automotive companies make to protect their industrial property rights. However, the high proportion of companies in the category of "cash cows" in mechanical engineering is somewhat surprising. It suggests that these companies underestimate the protection of industrial property rights and risk imitation of technical solutions, design and marking by competitors. Regarding the last quadrant of "question marks", the highest proportion of firms (52\%) in this quadrant is the NACE Divisions $10+11$, the lowest (8\%), the NACE Division 20. Companies in this group make a lot of effort to protect industrial rights, but fail to commercialize them sufficiently. Overall, when the sum in individual branches is made, most companies are in the categories of "problem children" and "cash cows" (32\% each), only about $15 \%$ of companies were included in the group of "super stars". These two groups are also dominant in the analysis across all branches. Such results point to a significant inhomogeneity of industries.

Table 2. Scores of effectiveness, efficiency and performance by branches

\begin{tabular}{|c|c|c|c|c|c|c|c|c|c|}
\hline \multirow[t]{2}{*}{ NACE } & \multicolumn{3}{|c|}{ Effectiveness } & \multicolumn{3}{|c|}{ Efficiency } & \multicolumn{3}{|c|}{ Performance } \\
\hline & Avg. & SD & Frontier & Avg. & SD & Frontier & Avg. & SD & Frontier \\
\hline $10+11$ & 0.59 & 0.33 & 5 & 0.33 & 0.32 & 4 & 0.16 & 0.19 & 0 \\
\hline 13 & 0.55 & 0.34 & 10 & 0.50 & 0.39 & 13 & 0.27 & 0.32 & 4 \\
\hline 16 & 0.57 & 0.38 & 4 & 0.63 & 0.36 & 6 & 0.30 & 0.25 & 0 \\
\hline 18 & 0.33 & 0.33 & 4 & 0.47 & 0.32 & 6 & 0.12 & 0.19 & 1 \\
\hline 20 & 0.20 & 0.21 & 4 & 0.33 & 0.35 & 18 & 0.06 & 0.07 & 0 \\
\hline 22 & 0.58 & 0.30 & 14 & 0.46 & 0.38 & 24 & 0.25 & 0.27 & 3 \\
\hline 23 & 0.53 & 0.32 & 8 & 0.39 & 0.37 & 15 & 0.18 & 0.22 & 0 \\
\hline 24 & 0.57 & 0.36 & 12 & 0.49 & 0.35 & 12 & 0.28 & 0.32 & 4 \\
\hline 25 & 0.35 & 0.26 & 12 & 0.48 & 0.36 & 73 & 0.15 & 0.17 & 1 \\
\hline 26 & 0.49 & 0.25 & 13 & 0.51 & 0.36 & 49 & 0.23 & 0.21 & 1 \\
\hline 27 & 0.49 & 0.26 & 11 & 0.50 & 0.36 & 50 & 0.23 & 0.22 & 2 \\
\hline 28 & 0.21 & 0.25 & 7 & 0.48 & 0.38 & 77 & 0.06 & 0.07 & 0 \\
\hline 29 & 0.81 & 0.26 & 15 & 0.61 & 0.37 & 12 & 0.47 & 0.34 & 6 \\
\hline 30 & 0.57 & 0.34 & 8 & 0.51 & 0.36 & 12 & 0.29 & 0.29 & 1 \\
\hline 31 & 0.64 & 0.40 & 6 & 0.78 & 0.25 & 8 & 0.45 & 0.28 & 2 \\
\hline Total by branches & 0.41 & 0.15 & 133 & 0.47 & 0.07 & 379 & 0.18 & 0.09 & 25 \\
\hline Total for all branches & 0.14 & 0.15 & 3 & 0.44 & 0.36 & 250 & 0.05 & 0.06 & 0 \\
\hline
\end{tabular}


Table 3. Number of companies in each matrix quadrants

\begin{tabular}{lllll}
\hline NACE & Cash cows & $\begin{array}{l}\text { Super } \\
\text { stars }\end{array}$ & $\begin{array}{l}\text { Problem } \\
\text { children }\end{array}$ & $\begin{array}{l}\text { Question } \\
\text { marks }\end{array}$ \\
\hline $10+11$ & 5 & 4 & 7 & 17 \\
13 & 6 & 7 & 13 & 10 \\
16 & 7 & 3 & 1 & 4 \\
18 & 13 & 2 & 9 & 4 \\
20 & 32 & 0 & 64 & 8 \\
22 & 14 & 24 & 12 & 32 \\
23 & 13 & 8 & 19 & 22 \\
24 & 9 & 12 & 12 & 11 \\
25 & 98 & 19 & 89 & 46 \\
26 & 50 & 31 & 44 & 32 \\
27 & 30 & 54 & 30 & 53 \\
28 & 131 & 1 & 117 & 25 \\
29 & 3 & 15 & 2 & 8 \\
30 & 8 & 12 & 10 & 9 \\
31 & 5 & 8 & 0 & 3 \\
\hline Total by & 424 & 200 & 429 & 284 \\
branch & & & & \\
Total & 564 & 0 & 735 & 38 \\
for all & & & & \\
branches & & & & \\
\hline
\end{tabular}

Correlation analysis between effectiveness, efficiency and performance proved (see Table 4) that, in overall terms, there is a moderately strong relationship between efficiency and performance and an even stronger relation between effectiveness and performance. Conversely, only negative, and very weak correlation was found between effectiveness and efficiency. These results are consistent with pilot studies (Budaj et al., 2015; Žižka, Turčok 2015). Thus, companies can improve their performance by increasing the effectiveness in protecting their industrial property rights or by increasing the efficiency of commercialization of these rights. On the other hand, it was identified that in some branches, the model of evaluating the performance of innovative companies is not valid (NACE Divisions 16,31 ) or it is only borderline (NACE Divisions $10+11,18,29)$.

The previous text suggests that there are differences between branches. To determine whether the effectiveness score or the efficiency score depends on the type of industry, analysis of variance was considered. The Shapiro-Wilk test was first implemented to verify the preconditions for the application of this method. All results were evaluated at a $5 \%$ level of significance. It was proved that the distribution of scores of effectiveness and efficiency is not normal (in both cases p-values $<0.0001$ ). The
Table 4. Pearson product moment correlations

\begin{tabular}{llll}
\hline NACE & $\begin{array}{l}\text { Effectiveness }- \\
\text { Performance }\end{array}$ & $\begin{array}{l}\text { Efficiency }- \\
\text { Performance }\end{array}$ & $\begin{array}{l}\text { Effectiveness }- \\
\text { Efficiency }\end{array}$ \\
\hline $10+11$ & $0.3053^{* * *}$ & $0.6330^{*}$ & $-0.3386^{* * *}$ \\
13 & $0.5130^{*}$ & $0.7571^{*}$ & -0.0110 \\
16 & $0.4878^{* * *}$ & 0.3804 & $-0.5237^{* *}$ \\
18 & $0.5676^{*}$ & $0.3737^{* * *}$ & -0.3005 \\
20 & $0.2270^{* *}$ & $0.7672^{*}$ & -0.1311 \\
22 & $0.3212^{*}$ & $0.7808^{*}$ & -0.1703 \\
23 & $0.3227^{* *}$ & $0.6904^{*}$ & $-0.2484^{* * *}$ \\
24 & $0.6104^{*}$ & $0.6962^{*}$ & 0.0157 \\
25 & $0.3755^{*}$ & $0.6652^{*}$ & $-0.2015^{*}$ \\
26 & $0.3087^{*}$ & $0.7911^{*}$ & $-0.1725^{* *}$ \\
27 & $0.3899^{*}$ & $0.7422^{*}$ & $-0.1596^{* *}$ \\
28 & $0.2087^{*}$ & $0.5260^{*}$ & $-0.4031^{*}$ \\
29 & $0.3398^{* * *}$ & $0.8138^{*}$ & -0.2085 \\
30 & $0.5417^{*}$ & $0.7176^{*}$ & -0.0259 \\
31 & $0.7572^{*}$ & 0.1533 & $-0.4995^{* *}$ \\
\hline Total & $0.2402^{*}$ & $0.6974^{*}$ & $-0.1970^{*}$ \\
\hline
\end{tabular}

Note: $* * * / * * *=$ significance at $\alpha=1 \%, 5 \%, 10 \%$ level.

choice of a test to verify homoscedasticity in both groups was derived from this fact.

When examining homoscedasticity in the group of effectiveness scores, Levene's test led to the rejection of the null hypothesis which assumes a compliance of variances in all branches ( $p$-value $<0.0001$ ). Significant differences between the variances in individual branches of industry were proved at a significance level of $5 \%$. The second Levene's test, where homoscedasticity of a group of efficiency scores was examined, led to non-rejection of the null hypothesis ( $p$-value $=0.2743$ ). Therefore, at a significance level of $5 \%$, it can be assumed that the variances of scores of efficiency are identical.

Given the outcome of the Levene's test, the analysis of variance cannot be used for examining the dependence of effectiveness scores on the different types of industries. Instead, the KruskalWallis test was chosen where medians in individual branches are compared. The value of the test statistic equals 362,406 and $p$-value $<0.0001$. Thus, the test proved that at a significance level of $5 \%$, there is dependence of the size of effectiveness scores on the branches. In order to determine in which branches the differences between the levels of effectiveness scores are significant, the outcome was supplemented by the 95 percent Bonferroni confidence intervals. Significant differences were found between the mean values of scores in 36 cases of pairwise comparison out of a total of 105 
possible pairs. The pairs of branches which show significant differences between mean values of effectiveness scores at the 95 percent confidence level are given in Table 5 .

It is apparent from Table 5 that the most frequent differences in the mean values of effectiveness scores show NACE Division 20 (12 differences of the possible 14), NACE Division 28 (12 differences) and NACE Division 25 (10 differences).

Table 5. Statistically significant differences between each pair of average ranks of effectiveness scores the Bonferroni method

\begin{tabular}{llll}
\hline $\begin{array}{l}\text { Pair of } \\
\text { branches }\end{array}$ & $\begin{array}{l}\text { Pair of } \\
\text { branches }\end{array}$ & $\begin{array}{l}\text { Pair of } \\
\text { branches }\end{array}$ & $\begin{array}{l}\text { Pair of } \\
\text { branches }\end{array}$ \\
\hline $10+11-20$ & $20-22$ & $22-25$ & $25-29$ \\
$10+11-25$ & $20-23$ & $22-28$ & $25-30$ \\
$10+11-28$ & $20-24$ & $23-25$ & $26-28$ \\
$13-20$ & $20-25$ & $23-28$ & $26-29$ \\
$13-28$ & $20-26$ & $24-25$ & $27-28$ \\
$16-20$ & $20-27$ & $24-28$ & $27-29$ \\
$16-28$ & $20-29$ & $25-26$ & $28-29$ \\
$18-22$ & $20-30$ & $25-27$ & $28-30$ \\
$18-29$ & $20-31$ & $25-28$ & $28-31$ \\
\hline
\end{tabular}

To investigate the dependence of scores of efficiency on the type of industry, one-way analysis of variance was used. The test result led to the rejection of the null hypothesis which states that the efficiency score is not dependent on the type of industry (F-Ratio $=3.3600$, p-value $<0.0001)$. Dependence of efficiency scores on the type of branch was proved at the significance level of $5 \%$, and thus, statistically significant differences between the average scores of efficiency in various branches. The given information may be supplemented by a degree of tightness of correlation. Eta squared has a value of 0.0340 , which means a very weak dependence of the efficiency score on the type of branch.

To determine pairs of branches in which there are statistically significant differences between the average scores of efficiency, a multiple range test was used which revealed 35 significant differences from the overall list of 105 possible. Table 6 shows pairs of branches which exhibit these statistically significant differences.

In Table 6, three branches can be found in which differences in average efficiency scores are more frequent. They are NACE Division 31 (12 differences of the possible 14), NACE Division 20 (11 differences) and NACE Division 10+11 (10 differences).
Table 6. Statistically significant differences between each pair of means of efficiency scores

\begin{tabular}{llll}
\hline $\begin{array}{l}\text { Pair of } \\
\text { branches }\end{array}$ & $\begin{array}{l}\text { Pair of } \\
\text { branches }\end{array}$ & $\begin{array}{l}\text { Pair of } \\
\text { branches }\end{array}$ & $\begin{array}{l}\text { Pair of } \\
\text { branches }\end{array}$ \\
\hline $10+11-13$ & $10+11-31$ & $20-26$ & $23-29$ \\
$10+11-16$ & $13-20$ & $20-27$ & $23-31$ \\
$10+11-24$ & $13-31$ & $20-28$ & $24-31$ \\
$10+11-25$ & $16-20$ & $20-29$ & $25-31$ \\
$10+11-26$ & $16-23$ & $20-30$ & $26-31$ \\
$10+11-27$ & $18-31$ & $20-31$ & $27-31$ \\
$10+11-28$ & $20-22$ & $22-31$ & $28-31$ \\
$10+11-29$ & $20-24$ & $23-26$ & $30-31$ \\
$10+11-30$ & $20-25$ & $23-27$ & \\
\hline
\end{tabular}

\section{DISCUSSION}

The previous text showed that the effectiveness and efficiency scores are affected by the branch in which the companies operate. On the other hand, the branch is only one of the factors on which the score depends. In addition, for the efficiency score, it was found that even if this dependence is significant, it is not too strong. Therefore, in further research, it will be desirable to focus on other sorting factors that could affect the score of efficiency, effectiveness, and hence, the resulting performance score. These other factors have not yet been studied and can be understood as a limitation of this research. One of the factors that may affect the company's performance and its components, are product platforms. Meyer and Lehnerd (1997) define the term as a set of subsystems and interfaces that form a common structure from which a stream of derivative products can be efficiently developed and produced. Further research of the authors will be oriented on the impact of product platforms on company performance.

Other factors affecting the effectiveness and efficiency include the number of employees, company size (small, medium, large), its turnover, profit, productivity or the type of innovation (product, process, marketing and organizational). The types of innovations can be another major factor affecting the proposed model to evaluate company performance. This article focuses on innovative companies that protect industrial property rights through enrolment in the registers of the Industrial Property Office of the Czech Republic. The majority of companies, however, implement innovations which are not protected in these registers. According to the calculation of CZSO (2014), in the years 2010-12 in the Czech Republic, non-technological innovations (marketing and organizational 
innovations) were introduced by almost one third of companies.

It should also be pointed out that company innovative activities are a fundamental factor in the strategic (and hence long-term) performance of companies. This means that innovation activities should be assessed in the longer term. For this reason, in this research the period of existence of the company on the market was considered an important performance factor reflecting the knowhow and experience of owners, managers and employees of the company.

Apart from closed innovation where the company controls its intellectual property, so that competition can not benefit from it, there is a new phenomenon: open innovation. Open innovation, according to Chesbrough (2003), is a paradigm implying that the company can provide some internal information to the market in order to create additional value. The reason is to support further innovation within the company, the use of research capacities of the company or the creation of a market for the external use of innovation.

\section{CONCLUSIONS}

The article showed that the overall performance of innovative companies can be divided into two pillars. The first pillar shows how companies can productively use money and intellectual capital to achieve the protection of their industrial property rights. The second pillar then determines what added value protected rights bring them. In the article, it was verified that this model applies generally in most of the surveyed branches except for the NACE Division 16 and NACE Division 31. In NACE Division 16 , it is probably due to a higher proportion of companies in the category of "cash cows" that devote only limited efforts to protect their industrial property rights, which is logically connected with the activity of these companies. Regarding the number of companies, NACE Division 31 is small and internally quite non-homogeneous.

The research results showed that in both components of performance, there is considerable potential for improvement. Only about $10 \%$ of companies act effectively in the protection of industrial property rights; and only $28 \%$ of companies can efficiently commercialize the protected industrial rights. In terms of calculated effectiveness and efficiency scores, the evaluated companies have the potential to increase their output in industrial rights by about $59 \%$ (while maintaining the same level of inputs), or more precisely, they have the potential to increase their economic output (value added) by $53 \%$ at a given level of registered industrial rights. The results, however, are influenced by the branch in which the companies operate.

Correlation analysis between the scores of effectiveness and efficiency proved a generally significant but weak and indirect dependence between the two variables. For 9 of the 15 assessed branches, there is not even any significant correlation between effectiveness and efficiency at the $5 \%$ level. However, there is a direct and in most branches (12 out of 15) moderately strong correlation between effectiveness and performance. This means that companies in these branches can enhance their performance by improving the effectiveness of their industrial property rights protection. For the efficiency pillar, the connection is on average even stronger, although at the $5 \%$ level, it is only significant for 12 branches. It can, therefore, be implied that companies can increase their performance by raising their efficiency when commercializing their industrial property rights.

Another objective of the article was to examine the difference in the performance of companies in terms of effectiveness and efficiency in relation to a branch. It was found that 69 pairs of branches (from the total of 105 pairs) are identical from the perspective of the average score of effectiveness, or in other words, for 70 pairs of branches, there is no statistically significant difference in the efficiency score. By contrast, in the remaining number of branch pairs, significant differences were found in the scores of effectiveness and efficiency. It can be said that the branch is, therefore, one of the factors that can be used to explain differences in company performance. At the same time, however, there are other factors affecting effectiveness and efficiency of companies which present a significant potential for further research. These factors include, for example, company innovation policy, whether in terms of the type of innovation or used approach to innovation (open, closed model). The level of exploitation of standardization and modularization of production and its impact on performance also appear to be promising areas for future research.

\section{ACKNOWLEDGEMENTS}

The article was supported by ESF operational programme "Education for Competitiveness" in the Czech Republic in the framework of project "Support of Engineering of Excellent Research and Development Teams at the Technical University of Liberec" No. CZ.1.07/2.3.00/30.0065. 


\section{REFERENCES}

AIP CR. 2015. Technological profile CR [online]. Association of innovative entrepreneurship CR. Available at: http://www.techprofil.cz/Default.asp?ChangeLang $=1$ [accessed 6 November 2015].

Aristovnik, A.; Obadić, A. 2015. The impact and efficiency of public administration excellence on fostering SMEs in EU countries, Amfiteatru Economic 17(39): 761-774.

Bisnode. 2015. Magnus Web CZ [online]. Available at: https://magnusweb.bisnode.cz [accessed 20 September 2015].

Budaj, P.; Hrnčiar, M.; Šlaichová, E.; Žižka, M. 2015. Multidimensional approach to increasing the efficiency of processes. Fribourg: Association Internationale Sciences, Éducation, Cultures, Traditions.

Charnes, A.; Cooper, W.; Lewin, A. Y.; Seiford, L. M. (Eds.). 1994. Data envelopment analysis: theory, methodology, and application. New York: Springer Science and Business Media.

Chen, H.; Xu, R.; Feng, Z. 2013. Evaluation of technological innovation efficiency in Chinese high-tech industry: two-stage relational DEA, Information Technology Journal 12(15): 3169-3173.

http://dx.doi.org/10.3923/itj.2013.3169.3173

Cheng, M.-Y.; Chen, C.-S. 2014. Preliminary planning efficiency evaluation for school buildings considering the tradeoffs of MOOP and planning preferences, Journal of Civil Engineering and Management 20(2): 211-222. http://dx.doi.org/10.3846/13923730.2013. 801890

Chesbrough, H. W. 2003. Open innovation: the new imperative for creating and profiting from technology. Boston, Massachusetts: Harvard Business School Press.

Chun, D.; Chung, Y.; Woo, Ch.; Seo, H.; Ko, H. 2015. Labor union effects on innovation and commercialization productivity: an integrated propensity score matching and two-stage data envelopment analysis, Sustainability 7(5): 5120-5138.

http://dx.doi.org/10.3390/su7055120

Cooper, W.; Seiford, L. M.; Zhu, J. (Eds.). 2011. Handbook on data envelopment analysis. 2nd ed. New York: Springer Science and Business Media.

Costa, R. 2012. Assessing intellectual capital efficiency and productivity: an application to the Italian yacht manufacturing sector, Expert Systems with Applications 39(8): 7255-7261. http://dx.doi.org/10.1016/j. eswa.2012.01.099

CZSO. 2014. Inovační aktivity podniků v České republice $v$ letech 2010-2012 [Innovative activities of enterprises in the Czech Republic in 2010-2012] [online]. Czech Statistical Office. Available at: https://www. czso.cz/documents/10180/20542669/e-21300314.pdf (in Czech) [accessed 8 November 2015].

Dlouhý, M. 2015. Long-term trends in efficiency of national health systems: an evaluation by two-stage data envelopment analysis, in Proceedings of the 33rd International Conference Mathematical Methods in Economics MME 2015, 9-11 September 2015, Cheb, Czech Republic, 127-132.
Düzakin, E.; Düzakin, H. 2007. Measuring the performance of manufacturing firms with super slacks based model of data envelopment analysis: an application of 500 major industrial enterprises in Turkey, European Journal of Operational Research 182(3): 1412-1432. http://dx.doi.org/10.1016/j. ejor.2006.09.036

Fiala, P.; Fábry, J.; Jablonský, J.; Pánková, V.; Černý, M.; Kalčevová, J.; Dlouhý, M. 2010. Operační výzkum - nové trendy [Operational research - new trends]. Prague: Professional Publishing (in Czech).

Grmanová, E. 2013. Aplikácia dvojstupňovej DEA metódy pri hodnotení efektívnosti poistovní a bánk [Application of two-stage DEA technique for efficiencies measurement of insurance companies and banks], Trendy Ekonomiky a Managementu 7(16): 9-15 (in Czech).

Hajiagha, S. H. R.; Akrami, H.; Zavadskas, E. K.; Hashemi, S. S. 2013. An intuitionistic fuzzy data envelopment analysis for efficiency evaluation under ucertainty: case of a finance and credit institution, E\&M Economics and Management 16(1): 128-137.

Ho, Ch. T.; Zhu, D. S. 2004. Performance measurement of Taiwan's commercial banks, International Journal of Productivity and Performance Management 53(5-6): 425-434. http://dx.doi.org/10.1108/17410400410545897

Horta, I. M.; Kapelko, M.; Lansink, A. O.; Camanho, A. S. 2016. The impact of internationalization and diversification on construction industry performance, International Journal of Strategic Property Management 20(2): 172-183.

http://dx.doi.org/10.3846/1648715X.2015.1123201

$\mathrm{Hu}$, X.; Liu, C. 2016. Profitability performance assessment in the Australian construction industry: a global relational two-stage DEA method, Construction Management and Economics 34(3): 147-159. http://dx.doi.org/10.1080/01446193.2016.1180415

Jin, Z.; Xia, B.; Li, V.; Li, H.; Skitmore, M. 2015. Measuring the effects of mergers and acquisitions on the economic performance of real estate developers, International Journal of Strategic Property Management 19(4): 358-367. http://dx.doi.org/10.3846/1648 715X.2015.1072858

Karlíček, M.; Chytková, Z.; Tyll, L.; Mohelská, H. 2014. Barriers of marketing effectiveness and efficiency within companies: a qualitative study, E\&M Economics and Management 17(4): 111-124.

http://dx.doi.org/10.15240/tul/001/2014-4-009

Klieštik, T. 2009. Kvantifikácia efektivity činností dopravných podnikov pomocou Data Envelopment Analysis [Quantification effectiveness activities traffic company by the rules of data envelopment analysis], E\&M Economics and Management 12(1): 133-145 (in Czech).

Knápková, A.; Homolka, L.; Pavelková, D. 2014. Využití Balanced Scorecard a vliv jeho využívání na finanční výkonnost podniků v ČR [Utilization of balanced scorecard and the effect ot its use on the financial performance of companies in the Czech Republik], E\&M Economics and Management 17(2): 146-160 (in Czech). http://dx.doi.org/10.15240/tul/001/2014-2-011 
Kočišová, K. 2014. Využívanie platobných kariet a efektívnost bánk [The use of credit cards and bank efficiency], E\&M Economics and Management 17(1): 121-139 (in Czech). http://dx.doi.org/10.15240/ tul/001/2014-1-010

Kumar, S.; Gulati, R. 2010. Measuring efficiency, effectiveness and performance of Indian public sector banks, International Journal of Productivity and Performance Management 59(1): 51-74. http://dx.doi. org/10.1108/17410401011006112

Lahouel, B. B. 2015. Eco-efficiency analysis of French firms: a data envelopment analysis approach, Environmental Economics and Policy Studies [online first], 1-22. Available at: http://link.springer.com/arti cle/10.1007\%2Fs10018-015-0115-4\#/page-1

Lebas M. J. 1995. Performance measurement and performance management, International Journal of Production Economics 41(1-3): 23-35. http://dx.doi.org/10.1016/0925-5273(95)00081-X

Lin, E. T. J.; Lan, L. W.; Chang, J. Ch. 2012. Measuring railway efficiencies with consideration of input congestion, Journal of Transportation Technologies 2(4): 315-323. http://dx.doi.org/10.4236/jtts.2012.24034

Liu, S-T.; Wang, R-T. 2009. Efficiency measures of PCB manufacturing firms using relational two-stage data envelopment analysis, Expert Systems with Applications 36(3): 4935-4939. http://dx.doi.org/10.1016/j. eswa.2008.06.014

Luptáčik, M. 2010. Mathematical optimization and economic analysis. New York: Springer Science and Business Media.

Meyer, M. H.; Lehnerd, A. P. 1997. The power of product platforms - building value and cost leadership. New York: The Free Press.

Nazarko, J.; Šaparauskas, J. 2014. Application of DEA method in efficiency evaluation of public higher education institutions, Technological and Economic Development of Economy 20(1): 25-44. http://dx.doi.org /10.3846/20294913.2014.837116

Ray, S. C. 2004. Data envelopment analysis: theory and techniques for economics and operations research. Cambridge: Cambridge University Press.

Rosenmayer, T. 2014. Using data envelopment analysis: a case of universities, Národohospodářský obzor Review of Economic Perspectives 14(1): 34-54. http:// dx.doi.org/10.2478/revecp-2014-0003

Salem, A. H.; Deif, A. M. 2014. An integrated approach to assess manufacturing greenness level, Procedia CIRP 17: 541-546. http://dx.doi.org/10.1016/j.procir.2014.01.127
Štamfestová, P. 2014. Ř́zení výkonnosti zpracovatelských podniků v ČR s důrazem na nefinanční aspekty podnikání [Business performance management in manufacturing companies in the Czech Republic with an emphasis on non-financial aspects of business], Politická ekonomie 62(4): 521-541 (in Czech).

Sueyoshi, T.; Goto, M. 2009. Can R\&D expenditure avoid corporate bankruptcy? Comparison between Japanese machinery and electric equipment industries using DEA - discriminant analysis, European Journal of Operational Research 196(1): 289-311. http://dx.doi.org/10.1016/j.ejor.2008.02.021

Sueyoshi, T.; Goto, M.; Omi, Y. 2010. Corporate governance and firm performance: evidence from Japanese manufacturing industries after the lost decade, European Journal of Operational Research 203(3): 724-736. http://dx.doi.org/10.1016/j.ejor.2009.09.021

Tausl Prochazkova, P.; Krechovska, M.; Lukas, L. 2015. Effectiveness of entrepreneurship policies: some evaluation research perspectives, Amfiteatru Economic 17(39): 706-722.

Triantis, K.; Otis, P. 2004. Dominance-based measurement of productive and environmental performance for manufacturing, European Journal of Operational Research 154(2): 447-464. http://dx.doi.org/10.1016/ S0377-2217(03)00181-4

Wagner, J. 2009. Měrení výkonnosti: Jak měřit, vyhodnocovat a využivat informace o podnikové výkonnosti [Performance measurement: how to measure, evaluate and use information about company performance]. Prague: Grada Publishing (in Czech).

Xie, X. M.; Zang, Z. P.; Qi, G. Y. 2015. Assessing the environmental management efficiency of manufacturing sectors: evidence from emerging economies, Journal of Cleaner Production [online first], 1-10. http://dx.doi.org/10.1016/j.jclepro.2015.08.006

Yang, J.-B.; Wang, H.-H.; Wang, W.-C.; Ma, S.-M. 2016. Using data envelopment analysis to support best-value contractor selection, Journal of Civil Engineering and Management 22(2): 199-209. http://dx.doi.org/10 .3846/13923730.2014.897984

Žižka, M. 2015. Evaluation of economic faculties using DEA, in Proceedings of the 33rd International Conference on Mathematical Methods in Economics MME 2015, 9-11 September 2015, Cheb, Czech Republic, 948-953.

Žižka, M.; Turčok, L. 2015. Data envelopment analysis as a tool for evaluating company performance, in Proceedings of the 12th International Conference Liberec Economic Forum 2015, 16-17 September 2015, Liberec, Czech Republic, 365-374. 